\title{
THE DEVELOPMENT OF YOUTH AND WOMAN ENTREPRENEURSHIP PROGRAM IN VILLAGE TOURISM THROUGH PARTNERSHIP
}

\author{
Sri UNTARI* \\ Universitas Negeri Malang, Faculty of Social Science, Civic Education Department, Indonesia, e-mail: sri.untari.fis@um.ac.id \\ Yusuf SUHARTO \\ Universitas Negeri Malang, Faculty of Social Science, Geography Department, Indonesia, e-mail: yusuf.suharto.fis@um.ac.id
}

Citation: Untari, S., \& Suharto, Y. (2020). THE DEVELOPMENT OF YOUTH AND WOMAN ENTREPRENEURSHIP PROGRAM IN VILLAGE TOURISM THROUGH PARTNERSHIP. GeoJournal of Tourism and Geosites, 33(4spl), 1538-1544. https://doi.org/10.30892/gtg.334spl14-605

\begin{abstract}
The development in tourism is nowadays a leading development in Indonesia; consequently, the tourism sectors is being developed up to the country sides. Tourism in rural areas is being estimated as an operational tool for integrating programs and supportin g activities among sectors which would bring significant impacts in social, economic, and cultural aspects while handled collaboratively. The research aimed to analyze: (a) the tourism potential in Wonorejo as the village tourism; (b) partnerships between the university, government, private sectors to develop the village tourism; (c) entrepreneurship opportunities for youth group (Karang Taruna), and women group (PKK) to develop the village tourism. The research was case study with qualitative approach. The informants included the village heads and officials, youth leaders, women leaders, and entrepreneurs. The data collection technique was used observation, interview, FGD, and documentation. The data were analyzed using domain analysis model with pattern matching. The results were (a) some potentials have been developed in the village, which is natural, historical and religious, and cultural tourism, (b) partnerships between universities and village governments made through a Memorandum of Understanding and the private sector was carried out without written documents. The partnership made the village government as regulators, facilitators, and investors, universities as initiators, facilitators, investors, and mediators, and the private sector as facilitators and marketers, (c) entrepreneurship opportunities have been developed by youth and women such as souvenir production, culinary experiences, outbound activities, and educational tours. The village government must design the village tourism to include in the village development plan program. The partnership be tween the university, government, and private sectors can be adapted and applied for rural communities' entrepreneurship in developing countri es.
\end{abstract}

Key words: partnership, entrepreneurship, village tourism, multi-religion.

\section{INTRODUCTION}

Partnerships between the government and the private sector have become popular in program development. Partnerships are formed because of mutual need between various parties (Vinogradov and Shadrina, 2018). The partnership that is built should provide benefits to all parties (Mtapuri and Giampiccoli, 2016). A good partnership is a partnership built based on a written agreement (Frank et al., 2000). A written agreement provides convenience for all parties to implement programs together (Frank et al., 2000; Vinogradov and Shadrina, 2018).

Partnerships between the government and the private sector often involve the community because they can provide direct benefits (Aryaningsih et al., 2018). Partnerships can also be built by involving universities. One of the assignments in university is community services. Community service must have a positive impact on community welfare (Untari, 2019). One of the community groups that need support is the community around coastal areas. The community lives very prone to poverty because it is very dependent on natural conditions (Ciolac et al., 2013; Garcia and Wanner, 2017). Therefore, it requires the cooperation of various parties in ensuring the life of coastal communities. Indonesia is a region with a large coastal area and a diversity of ethnic groups and religions. The diversity is a great potential for Indonesia to bring in tourists from abroad and increase the state revenue (Fieldston, 2019). To achieve these goals requires good management and planning in developing various potentials (Liu et al., 2019). In Indonesia, one of the great potentials to use is natural tourism and religious diversity. The attraction is supported by Indonesian characteristics that live in harmony, even in different ethnicities and religions. Rural communities in Indonesia still maintain this kind of life. One of the unique villages in Indonesia that has high level of diversity and lot of tourism potential is Wonorejo village in Situbondo district, East Java Province (Untari, 2019). Wonorejo village is well known as the reference for the harmonious village life model, so that this village is also known as the village tourism.

Wonorejo Village was chosen as the village tourism because of the harmony between religious communities such as Islam, Christian, Buddhism, Hinduism, and other local religions. Community life is very harmonious so that the village community has a distinctive characteristic, which is Gotong Royong (cooperation) (Untari, 2014; Wantoro, 2018). The cooperation is shown by the public cemeteries for all people, even though they are of different religions. Harmony also is shown by a mosque and a church place aside. It is a manifestation of Indonesia's motto Bhineka Tunggal Ika means different but still one. Wonorejo village has long been projected as a village tourism. Various tourist objects began to develop independently. However, there has been no intervention from the Situbondo district government through the Tourism Office to develop this tourist village (Untari, 2019; Wantoro, 2018). Therefore, a collaboration with the State University of Malang (UM) has been carried out through Kuliah Kerja Nyata (Community Service Program), Program Kreatifitas Mahasiswa (Student Community Service and Creativity Program), and the village development program so that the village tourism could provide benefits for the community welfare. Good partnership is partnership that involves the com munity, such as youth and women. This community group has the potential to develop for entrepreneurship. Accordingly, partnerships must provide big opportunities for youth and women to develop their entrepreneurship skills (Untari, 2019). Therefore, a specific study is needed related to the partnerships formed by universities, governments, and the private sectors that involve youth and women to develop village tourism.

\footnotetext{
${ }^{*}$ Corresponding author
} 


\section{METHODS}

The research used qualitative approach. The objective was to find the partnership between the university, private, and community to develop entrepreneurship programs for youth and women in Wonorejo village, Situbondo Regency. Data collection techniques included 1) in-depth interviews; 2) focus group discussion; 3) observation; 4) documentation (Yin, 2014).

Primary data were obtained by in-depth interviews using purposive sampling technique with key informants, such as the village heads "Mr. Sumanto", the Dean of Faculty of Social at the State University of Malang "Ms. Sumarmi", youth leaders, women leaders, a nd entrepreneurs. The group discussion forum was then held to obtain information about the government's performance in the village tourism development program and youth and women's entrepreneurship programs.
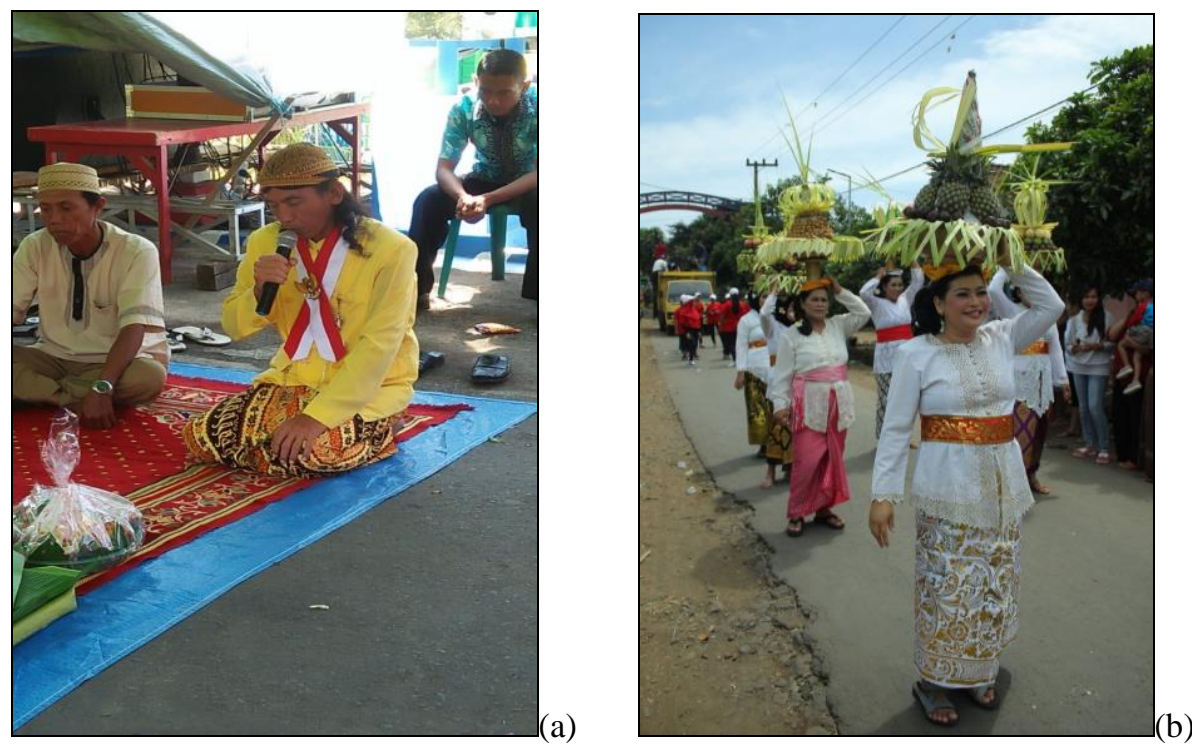

Figure 1. (a) The praying activity between religions during the Tumpeng Sewu event; (b) The Tumpeng Sewu convoy.

Table. 1 Interview Questions for key informants

\begin{tabular}{|l|l|}
\hline \multicolumn{1}{|c|}{ Reseacrh Focus } & \multicolumn{1}{c|}{ Questions } \\
\hline \multirow{3}{*}{ Tourism Development } & What is the potential for natural tourism in Wonorejo village? \\
\cline { 2 - 2 } & What is the potential for historical and religious tourism in Wonorejo village? \\
\cline { 2 - 2 } & What is the potential for cultural tourism in Wonorejo village? \\
\hline \multirow{2}{*}{ Partnership in tourism development } & What are the basic for the partnership in developing Wonorejo tourism village? \\
\cline { 2 - 2 } $\begin{array}{l}\text { Entrepreneurship opportunities in } \\
\text { the development of tourism villages }\end{array}$ & What is the role of local actors in tourism development of Wonorejo village? \\
\cline { 2 - 2 } & What kind of entrepreneurship are being developed by youth (Karang Taruna) and women (PKK) groups? \\
\hline
\end{tabular}

The data were analyzed using domain analysis techniques with pattern matching (explanatory/descriptive). The research used 3 stages of analysis shown below.

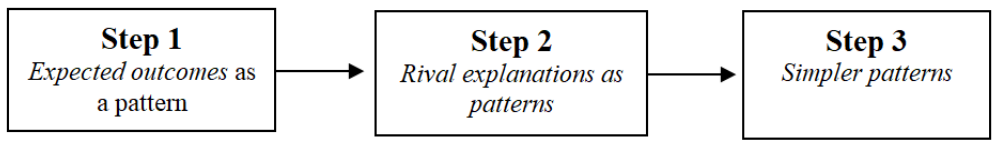

Figure 2. The Data Analysis Stages using Pattern Matching (Source: Yin, 2014)

Based on Figure 1, the stages of data analysis are explained as follows:

1. Expected outcomes as a pattern

In the early stages of data analysis, the researcher determined the answers to the predetermined problem formulations. The stage guided the researcher to develop the right instrument to be valid and can support the answers to the research problems that have been formulated.

2. Rival explanations as pattern

The stage was carried out by classifying the data according to the existing problem groups. Researchers compared the data sources and data collection techniques in order to focus on the problem. Researchers selected data and reduced irrelevant data in order to obtain clarity of answers to research problems accurately.

3. Simpler patterns

It is the final stage of data analysis activities. The researcher concluded by simplifying the problems following the problems that have been formulated.

\section{RESULTS AND DISCUSSION}

Wonorejo Village is located in Banyuputih District, Situbondo Regency, East Java Province. There is a gate written with Wonorejo Village as the Village tourism at the entrance. Wonorejo Village was introduced as a village tourism by the Regent of Situbondo, East Java, on 2 May 2015. Wonorejo Village consists of four small villages: Kendal village, Jelun village, Randuagung village, and Pandean village. Wonorejo village has 414,019 hectares, with landscape from the coast to mount of Baluran (Wantoro, 2018). In general, Wonorejo villagers work as farmers, fishers, ranchers, and minor traders. Based on the in-depth interviews, forum group discussions, and observations, the research results are explained as follows. 


\section{Tourism Development Priority}

Based on the in-depth interviews and focus group discussions (FGDs) held with the village officials, it showed that natural tourism is a priority to be developed as a leading tourist destination for the village tourism. The tourism potential includes:

a. Natural tourism

The potential is prioritized to be developed in Perengan Beach. The beach has completed several public facilities such as a prayer room, toilets, and shops. Perengan Beach is the pillar for Wonorejo village because it has many attractions. Perengan Beach is also used by Wonorejo Village to hold fishing competitions every year, Baluran Fishing Competition. The activity is an annual program held in collaboration with Wonorejo Village and Baluran National Park office. Besides, Wonorejo Village also has natural attractions such as the Bajulmati dam, Batu Bolong object, which has not been explored for national tourism products because residents still enjoy it.

b. Historical and religious tourism

The potentials that were chosen to be developed are historical and religious tourism. It is in the historical sites of Mbah Pande and Mbah Jenun's grave, which are considered the founders of the Pandean village or the forerunner of Wonorejo village. Currently, it is still being worked on simply. The peak session is during Suro month because the traditional ceremonies were centered on these two graves.

Another unique religious tourism in Wonorejo Village is the multi-religion. There is a mosque next to the church, $20 \mathrm{~m}$ away from the Randu Agung village. Muslims have dominated the community in Wonorejo village, but Christians can build churches after obtaining permission from the surrounding community and the village leaders. In another village, there is a mosque that stands next to the Christian community house. It proved that there is religious harmony in Wonorejo village. Other religious tourism in Wonorejo Village is the site of Candi Bang or the temple of money. The temple is known as a place to pray to God for getting aid.

c. Cultural tourism

Cultural tourism is carried out in events such as the Tumpeng Sewu event held on 10 Suro (Muharam). Tumpeng Sewu is an attraction in the village tourism that contains the uniqueness of the multicultural Wonorejo community. All people across religions, tribes, and groups are involved in offering prayers at the event. The prayer procedure is carried out in alternating Islam, Christian, Catholic, Hindu, and Buddhist ways.

One of the arts found in Wonorejo village is Kuda Lumping. It is often held during the village cultural events. Kuda Lumping is a dance that describes Wonorejo's forest cleavers, which are great at riding horses. Other dances characteristic of Wonorejo village is the Jaring Kambang dance, which describes fishers while at sea. Apart from that, there is also traditional music art, namely Karawitan and Hadrah Kuntulan, a combination of tambourines and other musical instruments often used during weddings. Wonorejo village originally had a national museum, but the museum was converted into a health center. Based on research findings, the priority of developing village tourismthrough partnerships included nature, religious, and cultural tourism. One of the activities that attract tourists is the Suro Tradition. The activity is an ancient tradition, so it needed to be preserved. The Suro tradition has become part of the life of the Javanese people so that it is still developing (Kurniawan, 2019; Riki, 2010). The development of selected tourism potential in Wonorejo village is expected to become a special interest in tourism. Tourists tend to appreciate the natural environment, culture, and special at tractions more (Priyanto, 2016). One of the tourists demand is the general atmosphere and environment of the tourist object (scenery, weather, attitudes, behavior) (Pascariu and Gabriela, 2006). It is following the village government's choices and the community to develop natural tourism potential. A new trend emerged, namely, a shift in tourists' interest to visit rural areas that present their natural beauty with cool air and various customs (Capocchi et al., 2019). Rural tourism has various traditional cultural values, folk art, folklore, and ethnography. These are based on traditions, and local wisdom is beautiful to tourists (Ciolac et al., 2013; Keyim, 2018; Marlina et al., 2020).

\section{Partnership between village government with the university and the private sector}

Partnership development between the State University of Malang (UM) and the Wonorejo village government has been established since 2018. The partnership was made through a Memorandum of Understanding, but the partnership between the village government and the private sector, such as the Baluran Tourism Park business unit and the village entrepreneurs, has not been made in the written document. The agreement between the university and the village government can be seen in Figure 3.
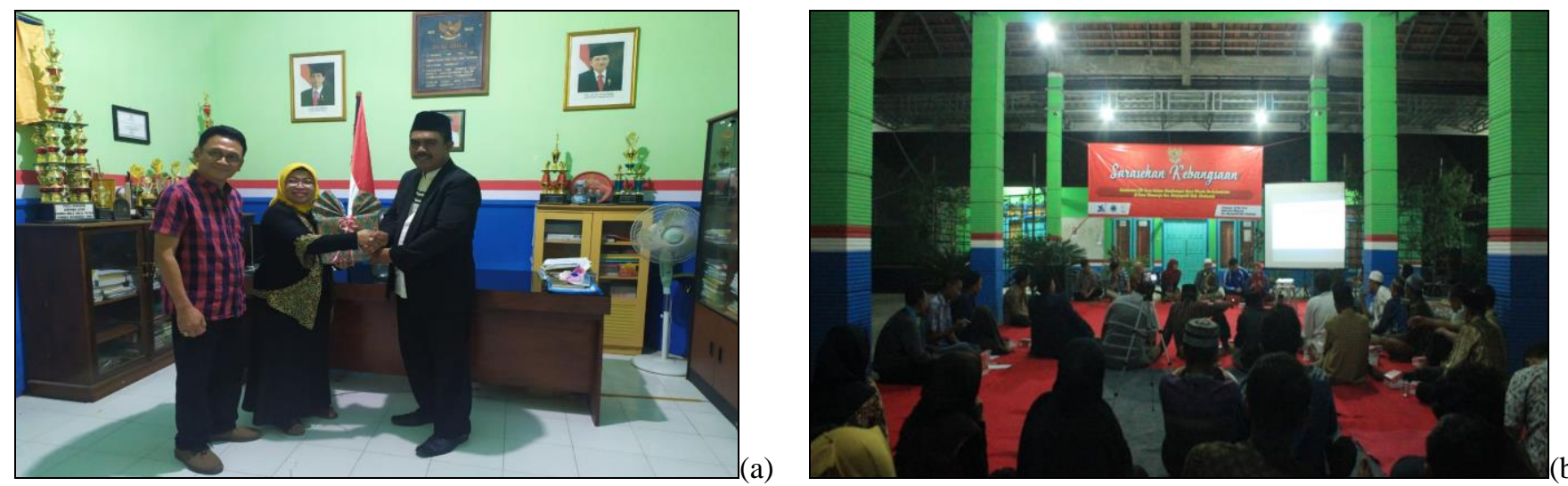

Figure 3. (a) Agreement between university and village government; (b) Discussion between university, village government, and local entrepreneu

Partnership development can be described as follows:

a. The Principles of Partnership Management

The principles of partnership management were stated in the Memorandum of Understanding between the university and the Wonorejo village government contained the following:

1) Cooperate in organizing Student Service and Creativity programs for society, research, and entrepreneurship.

2) Support in village development in governance, village tourism development, education and training for village officials, community empowerment (youth and women groups)

3) Cooperate in thematic Community Service Program $(\mathrm{KKN})$ for students as needed and within areas of expertise in the Faculty of Social.

4) Cooperate in agreement as a follow-up to the Memorandum of Understanding. The responsibilities and rights are arranged and agreed upon by both parties. 
Based on the agreement stipulated in this Memorandum of Understanding, it is valid for 3 (three) years from the time it was signed, and amendments can be made if desired by both parties. This Memorandum of Understanding can be extended for an additional period of up to 3 (three) years. There is an exception if one of the parties makes a written statement to terminate the Memorandum of Understanding at the latest 6 months beforehand. Both parties signed this Memorandum of Understanding on 2 July 2018 in Situbondo.

b. Roles Distribution of Partnership Actors

1) The village government

The role of the Wonorejo village government is to plan a village tourism development program. In this collaboration, the village government gives permission to carry out research and community service, provides space, prepares empowered human resources, facilitates the implementation of mentoring activities. Also, the Village Government provides a budget to develop entrepreneurship for Family Welfare Empowerment (PKK), attended by women and youth groups (karang taruna), as a villager 'SA' stated that the community will support activities to develop village tourism, especially to empower women and youth in Wonorejo village, and provide the necessary fund to develop village-owned entreprise (BUMdes) (interview. 7 August 2019). Another statement from the youth leader, Mr. SL, o stated that the Wonoroje village goverment were ready to collaborate with university, prepare infrastructur, and contribute in developing the national tourism village (Interview 7 August 2019). Based on the statement, it can be concluded that the role of the village government in this partnership is as (1) the regulator, determining rules and permits for the partnership to work; (2) facilitator, providing facilities and infrastructure in the entrepreneurial empowerment activities of the Youth and PKK; (3) investors, the village government shall provide budget funds by sharing with the university to implement partnerships.

2) The University

State University of Malang (UM) roles in research and community service activities. In 2019, various activities such as socialization, facilitation, discussions with elites, and mentoring were carried out. Also, t-shirt printing equipment was provided for the youth groups to produce printing as souvenirs. The important thing about this partnership is finding a partner for the marketing of community products.

The role of the university in the partnership as (1) facilitators, community service teams, and research teams to provide entrepreneurship training based on the needs of youth group (Karang Taruna) and woman group (PKK), (2) investors, the team from university helps procure printing equipment and manufacture souvenirs, t-shirts, and key chain; (3) mediators, the university has a role in finding partners for marketing youth group (Karang Taruna) and woman group (PKK) products.

3) The Private Sectors

The role is being pioneered by local entrepreneurs, the association of homestay owners, food sellers, and business units from Baluran National Park. The private sector assists in designing Baluran souvenirs that can be marketed in the Baluran National Park. The homestay owners also expressed the willingness to accept hand-made souvenirs from women and youth groups to be marketed to tourists. The head of the Baluran National Park business unit, Mr. "TR", stated that the business unit and showroom were ready to market handicrafts or souvenirs from youth and woman groups and assisted to develop more tourism products of Wonorejo village (Interview, 31 August 2019). The homestay owner, Mrs. "SM", also stated the homestay owners' group were ready to market the souvenir such as keychain or Wonorejo t-shirt to visitors or tourists (Interview, 31 August 2019).

Based on the research findings, the private sector roles as (1) facilitator, activities to assist in designing unique and distinctive souvenir products that can be marketed, and (2) product marketing. Based on the previous explanation, the roles of each party can be described as follows:

Table 2. The Actor Roles in Partnership

\begin{tabular}{|l|c|l|}
\hline \multicolumn{1}{|c|}{ Actor } & Position & \multicolumn{1}{c|}{ Roles } \\
\hline University & Colleges & $\begin{array}{l}\bullet \text { Provide training and mentoring in entrepreneurship skills } \\
\cdot \text { Provide equipment assistance } \\
\cdot \text { Mediating Karang Taruna and PKK partners with the private sector }\end{array}$ \\
\hline Village Government & $\begin{array}{c}\text { State } \\
\text { Institutions }\end{array}$ & $\begin{array}{l}\bullet \text { Permit to carry out research and community service by universities and local entrepreneurs } \\
\cdot \text { Provide business capital assistance for the youth and woman groups }\end{array}$ \\
\hline $\begin{array}{l}\text { Local entrepreneurs } \\
\text { - Homestay owner } \\
\text { - Village entrepreneur } \\
\text { - Tourist } \\
- \text { Management of Baluran National Park business units }\end{array}$ & Privates & $\begin{array}{l}\cdot \text { Provide assistance } \\
- \text { Support in marketing Karang Taruna and PKK products } \\
\bullet \text { Promotion of goods }\end{array}$ \\
\hline
\end{tabular}

The universities, private sectors, and government partnership is a triple helix relationship. The relationship has been established in the village tourism development even though it has not been formally described. It contrasts with the partnership principle, which requires a written agreement (Etzkowitz and Leydesdorff, 1995; Frank et al., 2000). The State University of Malang has taken the initiative in this partnership to facilitate activities. It is shown by shifting the government's role, which is assumed to lead the commanding officer (Untari, 2019). The government is used to regulating the implementation of program activities. However, in this partnership, the parties must interact outside the government to develop the village tourism (Utomo and Satriawan, 2017). The partnership built is an effective tool in the region's economic development (Frolova and Medvedeva, 2018). The development of youth groups (Karang Taruna) and women groups (PKK) entrepreneurship to develop the village tourism has proven that there is a link between synergy, partnership, and human development (Farazmand, 2009). The relationship between the parties in this partnership can be seen in the following figure.

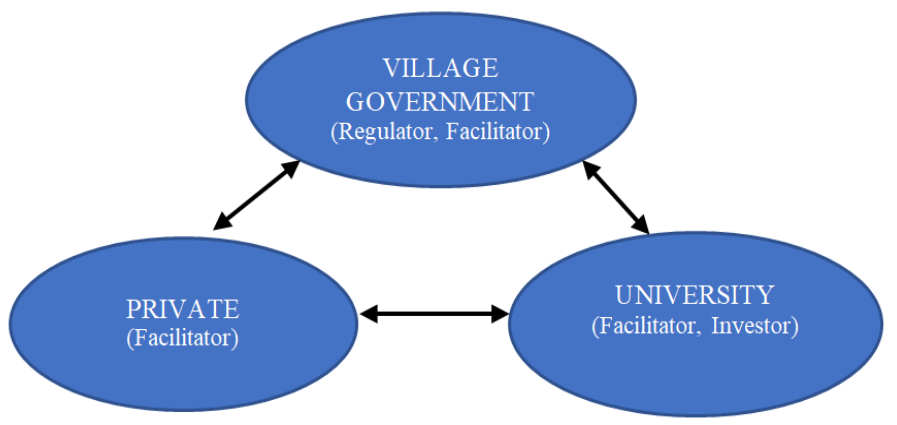

Figure 4. Partnership in Developing Village tourism 
The cooperation between the village government and universities is based on the agreement signed by the village head of Wonorejo and the Dean of State University of Malang. The agreement guaranteed by this binding agreement strengthens the partnership (Åberg, 2013; Ciolac et al., 2013; Sotiriadis and Shen, 2017). Meanwhile, the partnership with private sectors in a written agreement has not been implemented. Partnerships built without a written agreement are a necessity for the formation of normative institutions (Frolova and Medvedeva, 2018). Based on the discussion, the private party represented by the "TR" said that if an agreement is needed in the future, a memorandum of understanding will be made to clear this partnership program between each party's rights and obligations. The triple helix (figure 5) is essential to implement the partnerships (Bwana et al., 2015; Pradikta, 2017). One of the tourism resources is the partnerships between public and private parties involved or may be involved in tourism development (Mtapuri and Giampiccoli, 2016; Pascariu and Gabriela, 2006).

\section{Entrepreneurship Opportunities for Youth and Woman Groups}

The results showed that entrepreneurship opportunities for women through PKK and youth through Karang Taruna were extensive, described as follows:

a. Entrepreneurship opportunities in the woman group (PKK)

Business opportunities for PKK staff are producing simple souvenirs, eco-green batik headscarves, and typical culinary delights of Wonorejo village. One of the PKK leaders, Mrs. "TY", stated that the staff were given training, such as making flowers from kresek (plastic bags) and making eco-green batik, and also mentoring about tourism, souvenir, manufacturing practices and entrepreneurship opportunities in Baluran (interview 30 August 2019). Another opinion was also stated by Mrs. "SS" as one of the PKK administrators stated that there are many entrepreneurship opportunities such as culinary, snacks, clothes and headscarves from eco-green batik, baskets from used newspapers that can be marketed in the village tourism market (Interview, 30 August 2010). The results of in-depth interviews can identify opportunities for women in entrepreneurship in the village tourism as follows:

Table 3. Entrepreneurship Opportunities for woman group (PKK)

\begin{tabular}{|c|l|l|}
\hline No & \multicolumn{1}{|c|}{ Business Type } & \multicolumn{1}{|c|}{ Marketing } \\
\hline 1 & "WOKE" souvenir, headscarf, key chain & village, homestay, and Baluran showroom \\
\hline 2 & Culinary, processed from fishermen's catch & along the Parengan coast \\
\hline 3 & Snacks, pastries & village market \& Baluran Showroom \\
\hline 4 & Clothes, pajamas, eco-green batik t-shirts & village market \& Baluran Showroom \\
\hline
\end{tabular}

Based on the data analysis, it can be concluded that there are quite a lot of product and marketing opportunities by the PKK. It showed that the PKK group plays an important role in supporting a village tourism.

b. Entrepreneurship opportunities at Karang Taruna

The results showed entrepreneurship opportunities in the youth group, among others, making souvenirs in printing shirts containing the icon "WOKE" which stands for "Wonorejo Kebangsaan". The result of community service has developed a youth entrepreneurial spirit (Karang Taruna). Youth can develop superior products that support the development of the national tourism village. It is supported by the youth leader (Karang Taruna), Mr. "SP", stated that the digital printing machine received from the UM service team has pumped the enthusiasm to develop more local product of Wonorejo village, such as t-shirt (Interview, 30 August 2019).

Karang Taruna entrepreneurship opportunities are quite a lot if the village has developed to be the tourist destination, such as outbound themed nationalism. Youths can become facilitators, motivators, and tourist guides who come to the village tourism in Wonorejo village. Youth mentoring activities (Karang Taruna) can be seen in the following figure.
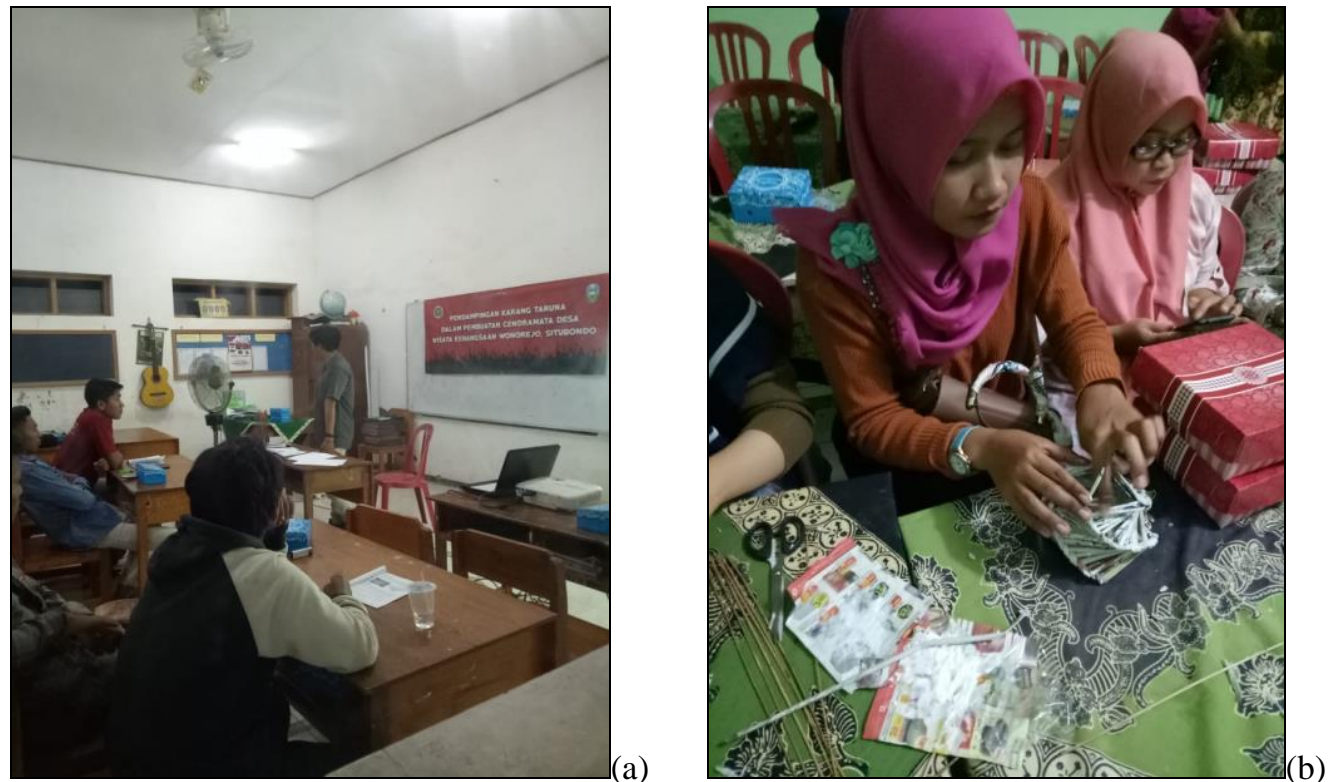

Figure 5. (a) Youth mentoring activities (Karang Taruna); (b) Mentoring and training activities for women group (PKK)

Table 4. Entrepreneurship Opportunities for youth group (Karang Taruna)

\begin{tabular}{|c|l|l|}
\hline No & \multicolumn{1}{|c|}{ Business Type } & \multicolumn{1}{c|}{ Marketing } \\
\hline 1 & "WOKE" souvenir & village, homestay, and Baluran showroom \\
\hline 2 & Outbound "Kebangsaan (nationalism)" for students & village forest collaborates with Baluran National Park \\
\hline 3 & Educational Tour, making nata de coco & Home industry of Nata de coco in Pandean village \\
\hline 4 & Other handicrafts, key chains, "WOKE" signature bags & village market \& Baluran Showroom \\
\hline
\end{tabular}


Based on the explanation, youth entrepreneurship opportunities (Karang Taruna) can be developed more widely. These opportunities are not only selling souvenirs but also offering educational activities according to the characteristics of the national tourism village.

The results were aimed at youth groups (Karang Taruna) and women groups (PKK) to provide knowledge and provide basic entrepreneurship skills. The following are opportunities created by entrepreneurship.

a. Entrepreneurship opportunities for women groups (PKK)

Support for PKK staff is carried out by providing information about tourism and training to produce simple souvenirs made from newspapers. Based on the information obtained during the observation, the staff has to attend training to make flowers from plastic bags. The results can be seen in front of the houses of residents of Wonorejo Village. Another training was Batik making known as eco-green batik. Meanwhile, training on making souvenirs has never been provided. The supports provided included knowledge about tourism, knowledge of the importance of souvenirs for tourist villages, and souvenirs' materials and practices. The results of the in-depth interviews showed that the knowledge needed by the PKK staff to support the village tourism is counseling about souvenirs making, newspapers recycling for souvenirs, and training in making handicrafts from used newspapers. The PKK group is highly desired by this activity. The entrepreneur's ability can increase family income so that people's lives can be more well-off (Kimmitt et al., 2020; Untari, 2019). Based on the interview, the t-shirt printing training was expected for counseling and support and, most importantly, product marketing. Based on the discussion, the PKK activities in Wonorejo village, Situbondo district, needed to be empowered. Entrepreneurship development for women can help improve society's creative economy (Juli, 2017; Riandika and Mulyani, 2020; Untari, 2019). The main components in women's empowerment are supports from all stakeholders (government, private sector, NGOs, and universities) (Metcalfe, 2011; Untari, 2019). The implementation of poverty reduction programs must be gender-responsive (Garcia and Wanner, 2017). The training must motivate participants to excel. Training is also expected to develop women's awareness of the importance of entrepreneurship in increasing family income (Kimmitt et al., 2020; Untari, 2019).

b. Entrepreneurship opportunities for youth groups (Karang Taruna)

The results showed that entrepreneurship opportunities in youth (Karang Taruna) were making souvenirs in the printing shirts. The community service activity has an impact on the development of the entrepreneurship for youth groups (Karang Taruna) (Aryaningsih et al., 2018). Entrepreneurship can develop superior products to support the village tourism (Untari, 2019). Entrepreneurship opportunities began to develop since the printing equipment, and digital printing machines arrived. The equipment was donations from the State University of Malang and some equipment owned by the Wonorejo Village government. The youth groups (Karang Taruna) also designed an outbound destination with the theme Bhinneka Tunggal Ika, which will become an educational tour in the village tourism. Includes opportunities to sell "WOKE" T-shirt products, key chains, and other handicrafts. Support for women groups (PKK) and youth groups (Karang Taruna) is essentially intended to empower community resources (Untari, 2019). It is aligned with the opinion that community-based tourism (CBT) development is a development model that provides the most significant opportunity for rural communities to participate in tourism development (Dewi, 2013; Donny and Mohd Nor, 2012; Sumarmi et al., 2020; Widowati et al., 2019). CBT is a tourism development activity carried out entirely by the community (Dewi, 2013; Donny and Mohd Nor, 2012; Widowati et al., 2019). Youth groups are required to develop entrepreneurship creativity (Kurniasari et al., 2016). In the end, creativity positively impacts the village tourism development (Egbali et al., 2011; Han et al., 2019).

\section{CONCLUSION}

Tourism potential that is a priority for developing Wonorejo village is natural tourism. Another unique potential to Wonorejo village than other villages in Indonesia is the outbound educational tour Bhineka Tunggal Ika. The partnership between the village government and universities is arranged in a written agreement, while the cooperation between the village government and ent repreneurs has not been formally carried out. Each party has its respective functions, such as the village government as regulators, facilitators, and investors, the universities as facilitators, assistants, and investors, and the local entrepreneurs as companions and marketing for Karang Taruna and woman (PKK) products. Entrepreneurship developed by youth groups (Karang Taruna) and women groups (PKK) has an excellent opportunity to be sold in a more extensive market.

The opportunities were provided for youth and women to develop village tourism. The results confirmed that the agreement was made officially to give the power to use their rights and obligations in managing the organization. A partnership built on a formal agreement protected all parties, including guarantees for the entrepreneurs to invest. The research was limited in wonorejo village as one of national village in Indonesia, and studied about the partnership in developing the village. Further reseacrh was needed to discuss other factors such as demographic, education and natural factor in developing national village. Entrepreneurship training is needed for youth and women because they can contribute to improving the welfare of rural communities in developing countries.

\section{Acknowledgement}

Thank you to Malang State University. Leader and community of Wonorejo Village, Situbondo District. This research does not have a conflict of interest with any party.

\section{REFERENCES}

Åberg, K.G. (2013). Governance and Partnership in Tourism Development: On the Elusiveness of Participation in Tourism. GERUM Department of geography and economic history. Umeå University. https://www.academia.edu/30647145/Governance_and_partnership_in_tourism_development_on_ the_elusiveness_of_participation_in_tourism

Aryaningsih, N.N., Arsana, M.M., Irianto, I.K., \& Meirejeki, N. (2018). Constructing of Business Competency Models and Entrepreneurial Spirit based on Tourism Support Services Community Participation in Creative Industries, 469-473. https://doi.org/10.2991/icss-18.2018.98

Bwana, M.A., Olima, W.H.A., Andika, D.O., \& Agong', S.G. (2015). Seizing an opportunity of a public-private partnership initiative for Agritourism development as a strategy for poverty reduction in Kisumu, Kenya. http://ir.jooust.ac.ke:8080/xmlui/handle/123456789/1534

Capocchi, A., Vallone, C., Pierotti, M., \& Amaduzzi, A. (2019). Overtourism: A Literature Review to Assess Implications and Future Perspectives. Sustainability, 11(12), 3303. https://doi.org/10.3390/su11123303

Ciolac, R., Csosz, I., Petroman, C., Petroman, I., Marin, D., Dincu, A.M., Rujescu, C., \& Stanciu, S. (2013). Public-private partnerships on rural tourism field in Europe an innovation for rural development-achievements and proposals. Scientific Papers Animal Science and Biotechnologies, 46(2), 387-392.

Dewi, M.H.U. (2013). Pengembangan Desa Wisata Berbasis Partisipasi Masyarakat Lokal di Desa Wisata Jatiluwih Tabanan Bali (Village Tourism Development Based on Local Community Participation in Jatiluwih Tourism Village, Tabanan Bali). Jurnal Kawistara, 3(2). https://doi.org/10.22146/kawistara.3976

Donny, S., \& Mohd Nor, N. (2012). Community-based Tourism (CBT): Local Community Perceptions toward Social and Cultural Impacts. Issues and Challanges in Tourism and Hospitality Resources. 1st Tourism and Hospitality International Conference, e Palma Ampang, Kuala Lumpur, Malaysia. 
Egbali, N., Bakhsh, A., Nosrat, E., \& Alipour, S. Khalil S. (2011). Effects of positive and negative rural tourism (case study: Rural Semnan Province). Journal of Geography and Regional Planning, 4(2), 63-76. https://doi.org/10.5897/JGRP.9000046

Etzkowitz, H., \& Leydesdorff, L. (1995). The Triple Helix-University-industry-government relations: A laboratory for knowledge based economic development. EASST Review, 14(1), 14-19.

Farazmand, A. (2009). Building Administrative Capacity for the Age of Rapid Globalization: A Modest Prescription for the Twenty-First Century. Public Administration Review, 69(6), 1007-1020. https://doi.org/10.1111/j.1540-6210.2009.02054.x

Fieldston, S. (2019). 'Our dollars are celebrities abroad': American tourists, consumption, and power after World War II. Journal of Tourism History, 11(2), 187-207. https://doi.org/10.1080/1755182X.2019.1622792

Frank, F., Smith, A., \& King, K. (2000). The partnership handbook. Human Resources Development Canada Ottawa.

Frolova, E., \& Medvedeva, N. (2018). Sotrudnichestvo biznesa i mestnoy vlasti: Problemy i novye vozmozhnosti [Cooperation between Business and Local Authorities: Problems and New Opportunities]. Public Administration Issues, 1, 181-196.

Garcia, A.S., \& Wanner, T. (2017). Gender inequality and food security: Lessons from the gender-responsive work of the International Food Policy Research Institute and the Bill and Melinda Gates Foundation. Food Security, 9(5), 1091-1103. https://doi.org/10.1007/s12571-017-0718-7

Han, H., Eom, T., Al-Ansi, A., Ryu, H.B., \& Kim, W. (2019). Community-Based Tourism as a Sustainable Direction in Destination Development: An Empirical Examination of Visitor Behaviors. Sustainability, 11(10), 2864. https://doi.org/10.3390/su11102864

Juli, S.B. (2017). Strengthening the Rural Women's Entrepreneurship Spirit in Facing the Asean Economic Community (Da'wah in the Economic Context of Society). Ijtimaiyya, Jurnal Pengembangan Masyarakat Islam, 10(1), 175-195. https://doi.org/10.24042/ijpmi.v10i1.2360

Keyim, P. (2018). Tourism Collaborative Governance and Rural Community Development in Finland: The Case of Vuonislahti. Journal of Travel Research, 57(4), 483-494. https://doi.org/10.1177/0047287517701858

Kimmitt, J., Muñoz, P., \& Newbery, R. (2020). Poverty and the varieties of entrepreneurship in the pursuit of prosperity. Journal of Business Venturing, 35(4), 105939. https://doi.org/10.1016/j.jbusvent.2019.05.003

Kurniasari, D., Suyahmo, S., \& Lestari, P. (2016). Peran Organisasi Karang Taruna dalam Mengembangkan Kreativitas Generasi Muda di Desa Ngembalrejo (The Role of the Youth Groups in Developing Youth Creativity in Ngunggungrejo Village). Unnes Civic Education Journal, 2(2). https://journal.unnes.ac.id/sju/index.php/ucej/article/view/2186

Kurniawan, S. (2019). Komunikasi Ritual Suroan pada Masyarakat Suku Jawa di Kota Bengkulu (Suroan Ritual Communication to Javanese Tribe Communities in Bengkulu City). Jurnal Ilmiah Syi'ar, 19(2), 138-150. https://doi.org/10.29300/syr.v19i2.2467

Liu, J., Jin, X., Xu, W., Fan, Y., Ren, J., Zhang, X., \& Zhou, Y. (2019). Spatial coupling differentiation and development zoning trade-off of land space utilization efficiency in eastern China. Land Use Policy, 85, 310-327. https://doi.org/10.1016/j.landusepol.2019.03.034

Marlina, Sumarmi, Astina, I.K. (2020). Sustainable Marine Ecotourism Management: A Case of Marine Resource Conservation based on Local Wisdom of Bajo Mola Community in Wakatobi National Park. GeoJournal of Tourism and Geosites, 32(4), 1317-1323. https://doi.org/10.30892/gtg.32419-575

Metcalfe, B.D. (2011). Women, empowerment and development in Arab Gulf States: A critical appraisal of governance, culture and national human resource development (HRD) frameworks. Human Resource Development International, 14(2), 131-148. https://doi.org/10.1080/13678868.2011.558310

Mtapuri, O., \& Giampiccoli, A. (2016). Towards a comprehensive model of community-based tourism development. South African Geographical Journal, 98(1), 154-168. https://doi.org/10.1080/03736245.2014.977813

Pascariu, G., \& Gabriela, D. (2006). The role of public-private partnership in the sustainable development of the rural tourist destinations. 46th Congress of the European Regional Science Association: “Enlargement, Southern Europe and the Mediterranean". Volos, Greece. https://www.econstor.eu/bitstream/ 10419/118425/1/ERSA2006_510.pdf

Pradikta, A.C. (2017). Building Partnership Across Rural Tourism Destination for Sustainability: A Case Study in Special Region of Yogyakarta, Some Challenges and Opportunities. Journal of Business on Hospitality and Tourism, 2(1), 87-96. https://doi.org/10.22334/jbhost.v2i1.44

Priyanto, P. (2016). Pengembangan Potensi Desa Wisata Berbasis Budaya Tinjauan Terhadap Desa Wisata di Jawa Tengah (Potential Development of CultureBased Tourism Villages an Overview of Tourism Villages in Central Java). Jurnal Vokasi Indonesia, 4(1). https://doi.org/10.7454/jvi.v4i1.53

Riandika, D., \& Mulyani, E. (2020). The Role of Entrepreneurship Development for Women Welfare in Rural Area. Jurnal Ekonomi Pembanguna, Kajian Masalah Ekonomi Dan Pembangunan, 21(1), 23-31-31. https://doi.org/10.23917/jep.v21i1.7921

Riki. (2010). Perayaan Satu Suro, Tradisi Malam Sakral Masyarakat Jawa: Tradisi - Situs Budaya Indonesia (Satu Suro Celebration, Javanese Sacred Night Traditions. Traditions - Indonesian Cultural Sites). Indonesia Kaya. https://www.indonesiakaya.com/jelajah-indonesia/detail/perayaan-satu-suro-tradisimalam-sakral-masyarakat-jawa

Sotiriadis, M., \& Shen, S. (2017). The contribution of partnership and branding to destination management in a globalized context: The case of the UNWTO Silk Road Programme. (No. 88145; MPRA Paper), University Library of Munich, Germany. https://ideas.repec.org/p/pra/mprapa/88145.html

Sumarmi, S., Kurniawati, E., \& Aliman, M. (2020). Community Based Tourism (CBT) to Establish Blue Economy and Improve Public Welfare for Fishing Tourism Development in Klatak Beach, Tulungagung, Indonesia. GeoJournal of Tourism and Geosites, 31(3), 979-986. https://doi.org/10.30892/gtg.31307-530

Untari, S. (2014). Kemitraan Pemerintah-Swasta di Bidang Pendidikan dalam Upaya Peningkatan Kualitas Pendidikan di Kota Malang (Kajian pada SMAN 10 Malang-Sampoerna Foundation). [Dissertations] (Public-Private Partnerships in Education in Efforts to Improve the Quality of Education in Malang City (Study at SMAN 10 Malang-Sampoerna Foundation), Brawijaya University.

Untari, S. (2019). Kolaborasi Perguruan Tinggi-Pemerintah Desa-Swasta dalam Mengembangkan Jiwa Kewirausahaan Pemuda dan Wanita Dalam Membangun Desa Wisata Kebangsaan [The collaboration of Higher Education-Village Government-Private in Developing Youth and Women Entrepreneurial Spirit in Building National Tourism Village]. Jurnal Praksis dan Dedikasi Sosial (JPDS), 2(2), 75-81. https://doi.org/10.17977/um032v2i2p75-81

Utomo, S.J., \& Satriawan, B. (2017). Strategi Pengembangan Desa Wisata di Kecamatan Karangploso Kabupaten Malang (Tourism Village Development Strategy in Karangploso District, Malang Regency). Neo-Bis, 11(2), 142-153. https://doi.org/10.21107/nbs.v11i2.3381

Vinogradov, D., \& Shadrina, E. (2018). Public-Private Partnerships as Collaborative Projects: Testing the Theory on Cases from EU and Russia. International Journal of Public Administration, 41(5-6), 446-459. https://doi.org/10.1080/01900692.2018.1426012

Wantoro, M. (2018). Woke! "Wonorejo Berkebangsaan” Rintisan Desa Bhineka Tunggal Ika sebagai Wahana Edukasi Nilai-Nilai Pancasila Melalui Pendekatan PRA (Participatory Rural Appraisal) dalam Rangka Pencapaian Program Nawacita [Woke! " Wonorejo Berkebangsaan " Pioneered the Village of Bhineka Tunggal Ika as a Forum for Education of Pancasila Values through the PRA (Participatory Rural Appraisal)]. Approach to Achieve the Nawacita Program, Laporan PKM-M.

Widowati, S., Ginaya, G., \& Triyuni, N.N. (2019). Penta helix model to develop ecotourism. International Journal of Social Sciences and Humanities, 3(2), 31-46. https://doi.org/10.29332/ijssh.v3n2.288

Yin, R.K. (2014). Case Study Research. SAGE Publications. https://books.google.co.id/books?id=Cdk5DQAAQBAJ 